Article

\title{
Impact Analysis of the Young Farmers' Support Program on Slovenian Dairy Sector Development Using Econometric Modeling Approach
}

\author{
Lazar Pavić $^{1}$, Jernej Turk ${ }^{1}$, Ivo Grgić ${ }^{2}$ and Jernej Prišenk ${ }^{1, *}$ \\ 1 Department of Agricultural economics and Rural Development, Faculty of Agriculture and Life Sciences, \\ University of Maribor, Pivola 10, 2311 Hoče, Slovenia; lazar.pavic@um.si (L.P.); jernej.turk@um.si (J.T.) \\ 2 Department of Agricultural economics and Rural Development, Faculty of Agriculture, University of Zagreb, \\ Svetošimunska st. 25, 10000 Zagreb, Croatia; igrgic@agr.hr \\ * Correspondence: jernej.prisenk@um.si; Tel.: +368-2320-9000
}

Received: 27 February 2020; Accepted: 18 March 2020; Published: 21 March 2020

\begin{abstract}
This study analyzes the effects that action 112 of the Rural Development Policy had on the socioeconomic status of Slovenian dairy farms. The data used in this paper were collected from Farm Accountancy Data Network (FADN), a database for applicants in action 112 (young farms transferees), from whose applications for participation in this action the data were obtained. Twenty-eight different econometric models were developed during the first stage of the research. The evaluation of the models was subsequently performed by applying valid statistical and econometric criteria. The results reveal the main positive effects that action $112 \mathrm{had}$ on socioeconomic indicators of the dairy farms: number of full-time labor power, number of head of large livestock, total revenue (in euros) and net value added. Statistically significant differences in benefits from action 112 among dairy farms were determined by using two sets of dummy variables: region and level of education. The research in the field of the effect of the rural development policy action support of young farmers on socioeconomics performance of milk farms can make a significant contribution to developing the researchers' work and policy makers' decisions. Furthermore, this research is important from the agronomic point of view, since its results support two of the basic goals of Common agricultural policy after 2020: environmental care and conservation of landscape and biodiversity.
\end{abstract}

Keywords: dairy farms; econometric models; rural development; socio-economic situation

\section{Introduction}

The dairy sector plays an integral role in the Slovenian agricultural market; namely, it represents about $14 \%$ of the total agricultural production value [1]. Its existence and preservation are very important from every aspect of sustainable rural development: economic, sociologic and agricultural. The support of dairy farmers is therefore crucial for both social and economic reasons [2].

Socioeconomic status is the position which the individual farmer occupies with reference to the prevailing average standards, material possession, social participation and economic factors [3]. These factors are often indicated as predictors of changes in ecosystems and as links between ecosystem services and human well-being [4]. For effective farm management, especially for dairy farms, it is very important to pay more attention to indirect drivers such as demographic, economic, sociopolitical and cultural factors [5]. The relationships between socioeconomic factors and their modeling is often established by using various kinds of regression models [6-9]. In 2018, authors [10] developed a translog profit model that ensures a better understanding of the economic situation of dairy farms from the view of their capability to adapt to ongoing changes in the milk market. 
The main aim of the European Union's Common Agricultural Policy (CAP) is acknowledging the structural problems in the agricultural sector by supporting productivity [11]. Agricultural or rural policy is often presented by a single set of policies, which tends to improve the economic performance of agricultural sectors by top-down implementation [12]. These policies are often designed through centralized planning, with an included vision of its creator [13].

Action 112 (Young farm transferees) presents one of the Common Agricultural Policy major actions. Its purpose was one-time financial assistance to young farm transferees for the first ownership of the farm. The European Agricultural Fund financed $75 \%$ of the project, while The Republic of Slovenia financed the remaining $25 \%$. The main objectives of this action were as follows: (1) to encourage the transfer of the farm to the younger generation and improve the age structure of farm holders; (2) to increase the development and production capacity of the farms taken over; and (3) to contribute to increasing productivity in agriculture. Pursuant to the Common Agricultural Policy (CAP) Regulation, investors of a natural person engaged in an agricultural activity on the territory of The Republic of Slovenia are aged 18 and 40, who turn 40 in the year when they are invited to the public tender and who take over the farm for the first time. The maximum amount which could be allocated to the transferee of the farm could go as high as 70,000 euros [1].

The main purpose of this study is to analyze how different groups of variables influenced different aspects of the socioeconomic status of the dairy farms that participated in action 112 of the Slovenian Rural Development Programme. The results give empirical insights into positive or negative consequences of this action. Simultaneously, they give proposals for future research in this field, providing practical guidelines for creating future rural policies. The obtained empirical results indicate: (1) the importance of rural policy and its actions to improve the socioeconomic situation of Slovenian dairy farms; (2) the importance of action 112 for the sustainable development of Slovenian dairy industry; (3) the effects that action 112 had on socioeconomic indicators of Slovenian dairy farms and its recommendations for improvement. Results of econometric models have been used to indicate the most important predictors of the socioeconomic status improvements for the dairy farms that participated in action 112. Another positive aspect of this paper is the importance it has for the agronomy, since the preservation of the farms from hilly mountain regions is one of the priority goals of the European Commission in future CAP [14]. Farms in these kinds of lees-favored areas (LFA) face serious problems with generation renewal. Livestock farming, especially milk production, is a key activity in most mountain regions worldwide, providing regular and secure income [15] and employment for mountain communities [16]. Since Slovenian mountain and hilly regions cover more than $70 \%$ of the country's total territory, the preservation of farming is crucial from both economic and social aspect [1]. This paper contributes to understanding the importance of the two of the nine CAP objectives, in particular (conserving landscape and biodiversity and encouraging generational renewal), as indicated by the European Commission in the next CAP (post-2020), which can be supported with money from the young-farm-transfers action. These facts could also be recognized as a theoretical background for this work.

As for the structure of this paper, in the next section, the data collection, the handling and the modeling strategy will be described, as well as how the models were developed. Furthermore, a detailed description of the econometric models for dairy farms in Slovenia that participated in action 112 will be given. The paper ends with a discussion and conclusions.

\section{Materials and Methods}

The data used in this paper were collected from FADN base for applicants in action 112 (Young farms transferees), as well as from their applications for participation in this action. The other data source was the Slovenian Agency for Agricultural Markets and Rural Development, which provided information about approval and funds payment. All the received information had been sorted into a few data groups: information about socioeconomic status of farms on the individual level, information about farming type, economic size, the amount of allocated funds from action 112, region, municipality, information 
about the applicants (gender, age and level of education) and information about agricultural holding. We received data for the period between 2010 and 2016, for 2188 Slovenian farms, of which 427 are dairy farms having participated in action 112.

All the data were presented on individual farm level. SPSS 24 Statistical Package (IBM®, Armonk, New York, USA) was used for the data analysis. The data were additionally processed and prepared for econometric analysis (Table 1). The data from 2010 and 2016 were used as difference between 2016 data and 2010 data.

Table 1. Input data list.

\begin{tabular}{|c|c|c|}
\hline \multicolumn{3}{|c|}{ Independent Variables } \\
\hline Variable Description & Variable Sign & Indicator \\
\hline Number of years of participation in the action & YEARS or YEARS_LOG & New \\
\hline Age of applicant (in years) & AGE or AGE_LOG & Social [17] \\
\hline Land in use surface (in ha) & LAND or LAND_LOG & Economic [17] \\
\hline Forest surface (in ha) & FOREST or FOREST_LOG & New \\
\hline Gender & GENDER & Dummy \\
\hline Is the applicant agricultural insurer? & AGRICULTURAL_INSURURER & Dummy \\
\hline Is farm located in the area with limited factors? & LFA & Dummy \\
\hline Is farm located in mountain hill area? & HMR & Dummy \\
\hline Is farm located in mountain elevation area? & MHR & Dummy \\
\hline Region & REGION & 11 dummy variables + reference category \\
\hline \multicolumn{3}{|c|}{ Dependent variables } \\
\hline Number of full-time labor power & $\mathrm{y}_{1}$ & Social [18] \\
\hline Number of head of large livestock & $\mathrm{y}_{2}$ & Economic [17] \\
\hline Total revenue (in thousand euros) & $\mathrm{y}_{3}$ & Economic [19] \\
\hline Coefficient of elasticity & $\mathrm{y}_{4}$ & Economic [2] \\
\hline Net added value & $\mathrm{y}_{5}$ & Economic [19] \\
\hline Farm family income & $\mathrm{y}_{6}$ & Economic [20] \\
\hline Farm family income/Number of full-time labor power & $\mathrm{y}_{7}$ & Economic [17] \\
\hline
\end{tabular}

In the first phase of the models' development, 28 models were initially created based on the input data presented in Table 1. The data measured on the nominal dichotomy scale were included in the model as dummy variables (gender, agricultural insurer, LFA-less favoured areas, HMR-hilly mountain regions and MHR - mountain hilly region).

For all dependent variables presented in Table 1, four different econometric models were developed: linear (LIN), logarithmic (LOG), linear-logarithmic (LIN-LOG) and logarithmic-linear (LOG-LIN). The models were developed in accordance with econometric modeling approaches adopted previously [21].

Using valid statistical and econometric criteria, we assessed the adequacy of the regression models' structure. The regression power between individual factors and selected analyzed indicators is also presented. As mentioned before, in the first step, 28 models were developed: four models for every dependent variable. This was followed by choosing the best model according to the results of statistical indicators, which was done for each dependent variable.

In the second stage of our research, additional independent dummy variables were included in the previously chosen best models: region and level of education. Bearing in mind that these variables have poorer measurement characteristics (measured on nominal or ordinal scale), the only possibility for their inclusion in regression models is via dummy variables. For every new variable, we included k-1 dummy variables, while k presents the number of an individual variable's categories, which had to be transformed into dummy variables. The category which does not have a dummy variable is a reference category. In this way, the problem of multicollinearity can be avoided.

In the third stage of our research, for statistically significant models, statistically significant differences between different categories were tested (Slovenian regions and applicants' level of education). 


\section{Results and Discussion}

For every dependent variable presented in Table 2, four different models were developed: linear (LIN), logarithmic (LOG), linear-logarithmic (LIN-LOG) and logarithmic-linear (LOG-LIN), 28 models in total. According to the highest values of multiple regression coefficients, the best model for every dependent variable was chosen (seven models). For dependent variables, coefficient of elasticity, farm family income and farm family income/number of full-time laborers, there was not a statistically significant model according to the values of statistical coefficients (low value of correlation coefficients, high values of Variance inflation factor (VIF) factors and no statistically significant F tests). The total number of developed models was four.

Table 2. Values of statistical and econometric criteria.

\begin{tabular}{|c|c|c|c|c|c|}
\hline Model & $\beta$ & $t$-Test & $p$-Value & Model Summary & Durbin-Watson \\
\hline 1 & 0.156 & 0.355 & 0.002 & $\begin{array}{l}\mathrm{R}=0.228 \\
\mathrm{R}^{2}=0.052 \\
\mathrm{~F}=2.242\end{array}$ & l \\
\hline 2 & 210.766 & 2.526 & 0.012 & $\begin{array}{c}\mathrm{R}=0.564 \\
\text { Adjusted } \mathrm{R}^{2}=0.297 \\
\mathrm{~F}=15.042 * * \\
\mathrm{R}=0.615\end{array}$ & 2.152 \\
\hline 3 & 8.906 & 17.417 & 0.000 & $\begin{array}{c}\text { Adjusted } \mathrm{R}^{2}=0.357 \\
\mathrm{~F}=17.179^{* *} \\
\mathrm{R}=0.233\end{array}$ & 2.246 \\
\hline 4 & 5413.117 & 0.330 & 0.049 & $\begin{array}{c}\text { Adjusted } \mathrm{R}^{2}=0.029 \\
\mathrm{~F}=2.152^{*}\end{array}$ & 1.851 \\
\hline
\end{tabular}

${ }^{*} p<0.01 ;{ }^{* *} p<0.05$.

Table 2 presents the values of statistical and econometric criteria. Correlation coefficient values (R) show medium strong relationships between variables included in the models. Adjusted R square values show that there are between $29.7 \%$ and $35.7 \%$ dependent variables variability explained with the independent variable's variability included in the separate model. Durbin-Watson coefficient values for all models are around two. It explains that there is no problem of autocorrelation in the models. According to the values of conducted F-tests, for all the presented models, we can conclude that at least one regression coefficient in every model is statistically significantly different from zero.

After the VIF (Variance Inflation Factor) coefficients (values less than 2) and Tolerance analysis (values higher than 0.2), the independent variables which do not satisfy these criteria were excluded from further analysis. Additionally, variables with regression coefficients $\beta$ around zero $(p>0.05)$, were excluded from further analysis. Independent variables which satisfy all of these criteria were included in the models and are displayed in Table 3.

\subsection{Number of Full-Time Labor Power}

According to the results displayed in Table 3, the conclusion can be made that the number of full-time labor power will probably increase if dairy farms participated longer in action 112 "young farm transferees". If an individual dairy farm participated in action 112 for one year longer, the number of full-time labor power would most likely increase on average by $7.3 \%$ of full-time labor power.

\subsection{Number of Heads of Large Livestock}

If the amount of eligible funds increases by 1000 euros, the number of heads of large livestock on dairy farms will probably increase on average by 18-21 heads of large livestock. If the sum of agriculture surface on dairy farm increases by one hectare, the number of heads of large livestock on dairy farms will possibly increase on average by 23 . The number of large livestock in dairy farms 
will also increase by 11 if the forest surface decreases for one hectare. The number of heads of large livestock will also increase if the dairy farm is in the area with limited factors.

Table 3. Models' formulation.

\begin{tabular}{cccc}
\hline Independent Variable & The Best Model & Model Number & Model \\
\hline $\begin{array}{c}\text { Number of full-time } \\
\text { labor power }\end{array}$ & LINEAR MODEL & 1 & $\mathrm{y}_{1}=0.16+0.073 \times$ YEARS \\
& & $\mathrm{y}^{2}=210.77+11.95 \times$ LFA + \\
& & $7.33 \times$ MHR $+18.62 \times$ \\
Aumber of head of large \\
livestock & LINEAR-LOGARITMIC & 2 & FOUNT_LOG $-11.13 \times$ \\
& MODEL & & AGRICULTURE_SUM_LOG \\
& & & $\mathrm{y}^{3}=8.91+0.09 \times$ YEARS + \\
& LOGARITMIC-LINEAR & & $0.13 \times$ AMOUNT + $0.05 \times$ \\
Total revenue & MODEL & 3 & LAND $-0.35 \times$ GENDER + \\
& & & $0.37 \times$ MHR \\
Net added value & LINEAR MODEL & 4 & Y5 $=5413.12+2541.56 \times$ \\
& & & YEARS $+593.59 \times$ LAND \\
\hline
\end{tabular}

\subsection{Total Revenue}

The total revenue of the dairy farm will increase by 96 euros if the dairy farms participates for one year longer in action 112, "young farm transferees". This is the amount of the total revenue for the whole period of participation, and we can recognize that duration of participation does not play any important role for increasing this type of amount. If the amount of eligible funds increases by 1000 euros, the total revenue of the dairy farm will increase by 134 euros. The total revenue of the dairy farm will increase by 50 euros if the land in use's surface increases by one hectare. The total revenue is likely to increase if the dairy farm is in a mountainous region. It would probably increase as well if the applicants for action 112 were male, and it would be likely to decrease if the applicants were female.

\subsection{Net Value Added}

A net value added is the value of the output less the values of both intermediate consumption and consumption of fixed capital $[16,19]$. The net value added of the dairy farm would probably increase by 2541.55 euros if the dairy farms were to participate for one year longer in action 112 "young farm transferees". It would also increase by 593.60 euros if the land for use in surface on the dairy farm increases by one hectare.

In the next step, eight additional models were developed by using two sets of dummy variables: region and level of education. Only two of the newly created models showed statistical significance (Table 4). The structure of these models can be written as follows:

$$
\begin{gathered}
\mathrm{Y}_{2}=286.63+11.62 \times \mathrm{LFA}+6.19 \times \mathrm{MHR}+18.81 \times \text { AMOUNT_LOG }-4.49 \\
\times \text { FOREST_LOG }+25,063.58 \times \mathrm{LAND} L \mathrm{LOG}+24.18 \times \mathrm{R}_{1}+14.66 \times \mathrm{R}_{2}+13.23 \times \mathrm{R}_{3} \\
+26.16 \times \mathrm{R}_{4}+8.39 \times \mathrm{R}_{5}+7.29 \times \mathrm{R}_{6}+26.52 \times \mathrm{R}_{7}+18.15 \times \mathrm{R}_{8}+24.41 \times \mathrm{R}_{10}+ \\
26.71 \times \mathrm{R}_{11}+15.69 \times \mathrm{R}_{12}
\end{gathered}
$$

where $R_{1}$ is Gorenjska region; $R_{2}$ is Goriška region; $R_{3}$ is South East Slovenia; $R_{4}$ is Koroška region; $R_{5}$ is Notranjsko-Kraška region; $R_{6}$ is Obalno-Kraška region; $R_{7}$ is Osrednjesloveska region; $R_{8}$ is Podravska region; $R_{9}$ is Pomurska region (reference category); $R_{10}$ is Savinjska region; $R_{11}$ is Srednjeposavska region; $R_{12}$ is Zasavska region.

$$
\begin{gathered}
\mathrm{Y}_{2}=225.52+10.82 \times \mathrm{LFA}+4.69 \times \mathrm{MHR}+13.11 \times \text { AMOUNT_LOG }-2.99 \times \text { FOREST_LOG } \\
+24.81 \times \text { LAND_LOG }-7.37 \times \mathrm{E}_{1}-10.49 \times \mathrm{E}_{2}-7.34 \times \mathrm{E}_{3}+1.60 \times \mathrm{E}_{5}
\end{gathered}
$$

where $E_{1}$ is primary school; $E_{2}$ is vocational education; $E_{3}$ is Secondary school; $E_{4}$ is college (reference category); $\mathrm{E}_{5}$ is university education or more. 
Table 4. Values of statistical and econometric tests.

\begin{tabular}{|c|c|c|c|c|c|c|}
\hline Model & B & $t$-Test & $p$-Value & Model Summary & $\begin{array}{l}\text { Sig. F } \\
\text { Change }\end{array}$ & Durbin-Watson \\
\hline Basic model & 210.77 & 2.53 & 0.012 & $\begin{array}{c}\mathrm{R}=0.564 \\
\text { Adjusted } \mathrm{R}^{2}=0.297 \\
\mathrm{~F}=15.042^{* *}\end{array}$ & 0.000 & 2.152 \\
\hline $\begin{array}{c}\text { Model } \\
\text { 2a-Equation (1) }\end{array}$ & 286.63 & 4.76 & 0.000 & $\begin{array}{c}\mathrm{R}=0.575 \\
\text { Adjusted } \mathrm{R}^{2}=0.305 \\
\mathrm{~F}=12.564^{* *}\end{array}$ & 0.004 & 2.157 \\
\hline $\begin{array}{c}\text { Model } \\
\text { 2b-Equation (2) }\end{array}$ & 225.52 & 3.68 & 0.000 & $\begin{array}{c}\mathrm{R}=0.571 \\
\text { Adjusted } \mathrm{R}^{2}=0.304 \\
\mathrm{~F}=18.760^{* *}\end{array}$ & 0.028 & 2.117 \\
\hline
\end{tabular}

F tests in Equations (1) and (2) compare these two models with model basic model and examine if the impact of the newly included variables were statistically significant. With a risk less than $1 \%$ for the model 2a-Equation (1) and less than 5\% for model 2b-Equation (2), we can conclude that at least one dummy variable from the set "region" and at least one dummy variable from the set "level of education" affects the dependent variable. The Durbin-Watson coefficient values suggest that there is no serial correlation in the models.

According to the previously presented results, in the third stage of the research, we investigated statistically significant differences between dairy farms in different Slovenian statistical regions, which include the statistically significant models $2 a$ and $2 b$ (Equations (1) and (2)). Seventeen new regression models were created, 12 new regression models-Equation (1) and 5 new regression modes-Equation (2), where every newly created dummy variable was once a reference category.

In Table 5, the regression coefficient values are represented for all newly added variables from the set "region". The Pomurska statistical region was determined as a reference category, since it showed statically significant differences from most of the other statistical regions. At a significance level $p<0.01$ statically significant differences were investigated between the Pomurska region and other regions, namely the Gorenjska region, Koroška region, Osrednjeslovenska region, Podravska region, Savinjska region and Zasavska region. In all these regions, the number of heads of large livestock on the dairy farms that participated in action 112 was statistically significant and increased approximately between 18.15 and 26.71, in comparison with the Pomurska region. These differences could be explained by presenting the characteristics of the Pomurska statistical region and comparing them to other regions. Although the Pomurska region is the most important area suitable for food production in Slovenia and agricultural holdings of this region cultivate almost $13 \%$ of all agricultural land in Slovenia and raise almost $12 \%$ of all the livestock [22,23], less than $10 \%$ of heads of livestock is bred in this region [24]. In addition to that, in comparison with all six regions with statically significant differences, this is predominantly a flatland, without high mountain regions [25].

Table 5. Regression coefficients for all dummy variables included in 2a model.

\begin{tabular}{cccccccccccc}
\hline Ref. & 1 & 2 & 3 & 4 & 5 & 6 & 7 & 8 & 10 & 11 & 12 \\
\cline { 2 - 12 } cat.9 & $24.18^{*}$ & 14.66 & 13.23 & $26.16^{*}$ & 8.39 & 7.29 & $26.52 *$ & $18.15^{*}$ & $24.41 *$ & $26.71^{*}$ & $15.69^{*}$ \\
\hline
\end{tabular}

Remarks: 1 = Gorenjska region; $2=$ Goriška region; $3=$ South East Slovenia; 4 = Koroška region; 5 = Notranjsko-Kraška region; 6 = Obalno-Kraška region; 7 = Osrednjeslovenska region; $8=$ Podravska region; $9=$ Pomurska region; 10 = Savinjska region; $11=$ Srednjeposavska region; $12=$ Zasavska region, ${ }^{*} p<0.01$.

In Table 6, the regression coefficient values for all newly added variables from the set level of education are presented. College education was determined as a reference category, since it showed statistically significant differences from most of the other educational levels. With a significance level of $p<0.01$, statistically significant differences in the number of heads of large livestock were investigated between Slovenian dairy farms that participated in action 112, with applicants holding a college degree 
in comparison with applicants having finished primary school only, vocation education or secondary school. On the dairy farms where farmers do not have a college degree, the number of large livestock, statistically significantly decreased approximately between 7 and 10 in comparison with the dairy farms where farmers have a college degree. These differences confirm the importance of the level of education in the agricultural sector as an important factor for successful farm operations $[26,27]$.

Table 6. Regression coefficients for all dummy variables included in $2 \mathrm{~b}$ model.

\begin{tabular}{ccccc}
\hline \multirow{2}{*}{ Ref. cat.4 } & $\mathbf{1}$ & $\mathbf{2}$ & $\mathbf{3}$ & $\mathbf{5}$ \\
\cline { 2 - 5 } & $-7.37^{* *}$ & $-10.49^{* *}$ & $-7.34^{* *}$ & 1.60 \\
\hline
\end{tabular}

Remarks: 1—primary school; 2-Vocational Education; 3-Secondary school; 4-College; 5-University education of more; ${ }^{* *} p<0.01$.

The direct positive effects from the action on selected socioeconomic factors of Slovenian farmers have an immediate impact on the first of the challenges presented-contributing to growth in the workplace supported by innovation throughout transition to new production models. Additionally, increasing the total income of the farm, the income of the farm family, combined with the counting of full-time laborers and the number of the main livestock on the farm directly contribute to growth and increase the number of working positions.

The new insights into the skills in the professionalism of young farmers in connection with strategically planned measures for the implementation of the common agricultural policies can have a positive impact on the resilience of the entire agricultural sector to cope with the various hazards [28]. The importance of this fact is recognized through the AKIS (Agricultural Knowledge and Innovation Systems) [29]. Consequently, this led to an additional increase in the competitiveness of the agricultural sector, which became more resistant to various types of economic, sanitary and environmental crises. Finally, the intermediary actions to address the environmental challenges of the Common Agricultural Policies after 2020 are worth mentioning. Given the social need for young farmers to have different attitudes toward this, the agricultural activity after 2020 will be able to respond positively to the environmental challenges related to economic relations within the context of management of natural resources (to provide opportunities for diversification of agricultural activities in view of the rural area as a region together with agriculture in other non-agricultural areas). On the basis of the results presented, additional investment in restricted areas (LFAs) was recommended, as it was reported that the holdings in the indicated areas had reached the plate, which provided assistance to young people who had taken over with other holdings.

\section{Conclusions}

The purpose of action 112 of the Slovenian Rural Development Programme was a one-time financial assistance to young farm transferees for the first ownership of a farm. This program had a positive impact on the economic situation of the dairy farms, as well as on the general demographic development of Slovenian rural regions. That is the reason why this action was recognized as being extremely positive by farmers.

The results presented in this study could be a useful framework for further creation of CAP for the next financial perspective (2021-2027). Financial support to the young farmers has positive benefits for the Slovenian milk sector. Consequently, it also ensures a better position in the supply chain, through equipment improvement.

The presented results bring numerous positive effects on Slovenian dairy farms. Firstly, it was proven that the number of full-time labors power on Slovenian dairy farms who participated in action 112 , "young farm transferee", increased on average by $7.3 \%$ for every year of their participation in this action. In other words, human resources are a crucially important aspect of agriculture system with its important role in long-term sustainability. An increasing number of large livestock is the second positive impact of action 112. The important predictors of its growth were the amount of eligible funds 
for the dairy farm by increasing the sum of agriculture surface, decreasing the forest surface and the dairy farm location in the area with limited factors. Increasing the number of large livestock directly influences the increased production capacity of the dairy farms. This is especially important for the socioeconomic and demographic situation of the areas with limited factors. In the next part, it was also determined that the region in which the farm is located, as well as the level of applicants' education had a statistically significant impact on the number of large livestock on the dairy farm. With a significance level $p<0.01$ statically significant differences were investigated between Pomurska region and the following regions: Gorenjska, Koroška, Osrednjeslovenska, Podravska, Savinjska and Zasavska. In all these regions, the number of heads of large livestock on the dairy farms that participated in action 112 statistically significantly increased. On the other hand, the level of the education of the applicants showed a positive impact on the number of heads of large livestock. On the dairy farms where farmers do not hold a college degree, the number of large livestock statistically significantly decreased.

Finally, it is important to emphasize the value of action 112 on the economic aspects of dairy farms business, such as the total revenue and the net value added. The important predictors of the total revenue of the dairy farms' increase are number of years during which an individual farm participated in the action, the amount of eligible funds, the area of the land in use, the location of the dairy farm in the mountain elevation and the gender of the applicants (male farmers). For the net value added, these predictors are the surface of the land in use and the number of years during which the individual farm participated in action 112.

Future research should focus on analyzing the data for all the farms that participated in action 112 in order to investigate the effects from this action upon all agricultural sectors by developing specific econometric models. It would be useful to discover statistically significant differences between dairy farms and farms operating elsewhere with different products. The information provided by this approach provides an excellent base for establishing further agricultural policy objectives. Limitations of the research can be recognized in the part of including input data which could have been based on more specific level and could have given the characteristics of farms for analyzed EU members.

Author Contributions: Conceptualization, J.P., L.P. and J.T.; methodology, L.P., J.P. and J.T.; software, L.P.; validation, J.P., L.P. and J.T.; formal analysis, L.P. and J.P.; investigation, L.P. and J.P.; data curation, J.P. and L.P.; writing-original draft preparation, L.P. and J.P.; writing-review and editing, L.P., J.P., J.T. and I.G.; supervision, J.P.; project administration, J.P. All authors have read and agreed to the published version of the manuscript.

Funding: This research received no external funding.

Acknowledgments: This research was supported by the project V4-1608 (B): Učinki in perspektive SKP na slovensko kmetijstvo in podeželje/Impacts and perspectives of the CAP on Slovenian agriculture and rural areas, financed by the Slovenian Research Agency (ARRS).

Conflicts of Interest: The authors declare no conflict of interest.

\section{References}

1. Ministry of Agriculture, Forestry and Food. Available online: https://www.gov.si/drzavni-organi/ministrstva/ ministrstvo-za-kmetijstvo-gozdarstvo-in-prehrano/ (accessed on 18 August 2019).

2. Prišenk, J.; Borec, A.; Janžekovič, M.; Grgić, I.; Pažek, K.; Rozman, Č.; Turk, J. The economic viability of value-based food chain for dairy farms in mountain regions: An econometric analysis approach. Mljekarstvo 2016, 66, 231-238. [CrossRef]

3. Raghav, S.; Sen, C. Socio-economic status of farmers and their perception about technology adoption: A case study. Econ. Bus. Rew. 2014, 2, 7-13.

4. Beilin, R.; Lindborg, R.; Stenseke, M.; Pereira, H.; Liausas, A.; Slatmo, E.; Queiroz, C. Analyzing how drivers of agricultural land abandonment affect biodiversity and cultural landscapes using case studies from Scandinavia, Iberia and Oceania. Land Use Policy 2014, 36, 60-72. [CrossRef]

5. Hou, Y.; Zhou, S.; Burkhard, B.; Muller, F. Socioeconomic influences on biodiversity, ecosystem services and human well-being: A quantitative application of the DPSIR model in Jiangsau, China. Sci. Total Environ. 2014, 490, 102-1028. [CrossRef] [PubMed] 
6. Doobs, C.; Kendal, D.; Nitshke, C. Multiple ecosystem services and disservices of the urban forest establishing their connections with landscape structure and sociodemographics. Ecol. Indic. 2014, 43, 44-55. [CrossRef]

7. Pažek, K.; Turk, J.; Hari, S.; Rozman, Č.; Prišenk, J. Multi-criteria and econometric evaluation of dairy products. Mljekarstvo 2014, 64, 127-136.

8. Zhang, Z.; Gao, J.; Fan, X.; Lan, Y.; Zhao, M. Response of ecosystem services to socioeconomic development in the Yangtze River basin, China. Ecolog. Ind. 2017, 72, 481-493. [CrossRef]

9. Rodgirguez-Loinaz, G.; Alday, J.; Onaindia, M. Multiple ecosystem services landscape index: A tool for multifunctional landscapes conservation. J. Environ. Manag. 2015, 147, 152-163. [CrossRef] [PubMed]

10. Prišenk, J.; Grgić, I.; Zrakić, M.; Turk, J. Value-based food chains as an opportunity to improve the economic situation of dairy farms: A translog profit function approach. Mljekarstvo 2018, 68, 224-233. [CrossRef]

11. Koopmans, M.; Rogge, E.; Mettepenningen, E.; Knickel, K.; Šumane, S. The role of multi-actor governance in aligning farm modernization and sustainable rural development. J. Rur. Stud. 2018, 59, 252-262. [CrossRef]

12. Shucksmith, M. Disintegrated rural development? Neo-endogenous rural development, planning and place-sharing in diffused power contexts. Socio. Rur. 2009, 27, 275-287.

13. Ward, N.; Brown, D. Placing the rural in regional development. Rur. Stud. 2009, 43, 1237-1244. [CrossRef]

14. European Commission. Available online: https:/ec.europa.eu/info/food-farming-fisheries/key-policies/ common-agricultural-policy/future-cap_en (accessed on 8 March 2020).

15. Bernet, T.; Staal, S.; Walker, T. Changing milk production trends in Peru. Small-scale highland farming versus coastal agribusiness. Mt. Res. Develop. 2001, 21, 268-275. [CrossRef]

16. Malla, Y. Dairy farming in mountain areas. Mt. Res. Dev. 2007, 27, 291-292. [CrossRef]

17. Yadav, K.; Revanna, M.L. A study on socio-economic status of the farm women of Tumakuru district of Karantaka State, India. Int. J. Pure Appl. Biosci. 2017, 5, 309-314. [CrossRef]

18. Aggarwal, O.P.; Bhasin, S.K.; Sharman, A.K.; Chhabra, P.; Aggarwal, K.; Rajoura, O.P. A new instrument (scale) for measuring the socioeconomic status of a family: Preliminary study. Indian J. Commun. Med. 2005, 30, 111-114.

19. EU Farm Economics Overview FADN (EFEO). Available online: www.ec.europa.eu/agriculture/rica/pdf/ report_2006.pdf (accessed on 31 August 2019).

20. Bolarinwa, K.K.; Fakoya, E.O. Impact of farm credit on farmers socio-economic status in Ogun State, Nigeria. J. Soc. Sci. 2011, 26, 67-71. [CrossRef]

21. Gujarati, D.N.; Porter, D.C. Basic Econometrics; Mass, McGraw-Hill: New York, NY, USA, 2009.

22. Glossary of Statistical Terms (GST). Available online: https://stats.oecd.org/glossary (accessed on 31 August 2019).

23. Cunder, T. Kmetijstvo v Pomurju Danes in Jutri. Pomurje: Trajnostni Regionalni Razvoj ob Reki Muri. (Agriculture in Pomurje Today and Tomorrow. Pomurje Region: Sustainable Regional Development along the Mura River) Zbornik; Zveza geografov Slovenije: Ljubljana, Slovenia, 2009.

24. Chamber of Agriculture and Commerce of Slovenia (CACS). Available online: www.kgzs-ms.si (accessed on 16 August 2019).

25. Kikec, T. Geografska tipizacija Prekmurja glede na občutljivost na sušo. Geogr. Vestn. Časopis Geogr. Sorodne Vede. 2015, 87, 23-41.

26. Kumbhakar, S.; Gnosh, S.; McGuckin, T. A generalized production frontier approach for estimating determinants of inefficiency in U.S. Dairy farms. J. Bus. Econ. Stat. 1991, 9, 279-286.

27. Rozelle, S.; Guo, L.; Shen, M.; Hughart, A.; Giles, J. Leaving China's farms: Survey results of new paths and remaining hurdles to rural migration. China Q. 1999, 158, 367-393. [CrossRef]

28. ARC 2020. Available online: https://www.arc2020.eu/what-farmers-know-optimising-this-knowledge/ (accessed on 9 March 2020).

29. European Commission. Available online: https:/ec.europa.eu/info/sites/info/files/food-farming-fisheries/ key_policies/documents/building-stronger-akis_en.pdf (accessed on 8 March 2020).

(C) 2020 by the authors. Licensee MDPI, Basel, Switzerland. This article is an open access article distributed under the terms and conditions of the Creative Commons Attribution (CC BY) license (http://creativecommons.org/licenses/by/4.0/). 